\title{
SRS Burial Ground Complex: Remediation in Progress
}

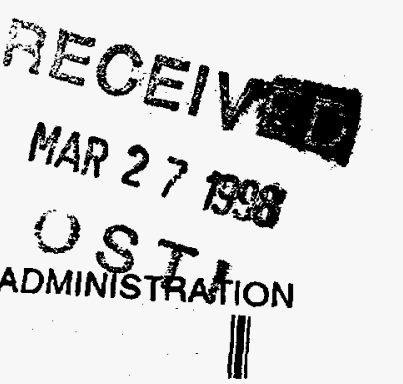

by

M. Griffin

Westinghouse Savannah River Company

Savannah River Site

Aiken, South Carolina 29808

B. Crapse

s. Cowan

\section{INFORMATION ONLY}

\section{MASTER}

DOE Contract No. DE-AC09-96SR18500

This paper was prepared in connection with work done under the above contract number with the U. S.

Department of Energy. By acceptance of this paper, the publisher and/or recipient acknowledges the U.S. Government's right to retain a nonexclusive, royalty-free license in and to any copyright covering this paper, along with the right to reproduce and to authorize others to reproduce all or part of the copyrighted paper. 


\section{DISCLAIMER}

This report was prepared as an account of work sponsored by an agency of the United States Govermment. Neither the United States Government nor any agency thereof, nor any of their employees, makes any warranty, express or implied, or assumes any legal liability or responsibility for the accuracy, completeness, or usefulness of any information, apparatus, product, or process disclosed, or represents that its use would not infringe privately owned rights. Reference herein to any specific commercial product, process, or service by trade name, trademark, manufacturer, or otherwise does not necessarily constitute or imply its endorsement, recommendation, or favoring by the United States Government or any agency thereof. The views and opinions of authors expressed herein do not necessarily state or reflect those of the United States Government or any agency thereof.

This report has been reproduced directly from the best available copy.

Available to DOE and DOE contractors from the Office of Scientific and Technical Information, P.O. Box 62, Oak Ridge, TN 37831; prices available from (615) 576-8401.

Available to the public from the National Technical Information Service, U.S. Department of Commerce, 5285 Port Royal Road, Springfield, VA 22161. 


\section{DISCLAIMER}

Portions of this document may be illegible electronic image products. Images are produced from the best available original document. 


\title{
THE BURIAL GROUND COMPLEX AT THE SAVANNAH RIVER SITE: REMEDIATION IN PROGRESS
}

\begin{abstract}
Closure of the various areas in the Burial Ground Complex (BGC) represents a major step in the reduction of risk at the Savannah River Site (SRS) and a significant investment of resources. The Burial Ground Complex occupies approximately 195 acres in the central section of the SRS. Approximately 160 acres of the BGC consists of hazardous and radioactive waste disposal sites that require remediation. Of these source acres, one-third have been remediated while two-thirds are undergoing interim or final action. These restoration activities have been carried out in a safe and cost effective manner while minimizing impact to operating facilities. Successful completion of these activities is in large part due to the teamwork demonstrated by the Department of Energy, contractor/subcontractor personnel, and the regulatory agencies. The experience and knowledge gained from the closure of these large disposal facilities can be used to expedite closure of similar facilities.
\end{abstract}

\section{INTRODUCTION}

The Burial Ground Complex at the Savannah River Site occupies approximately 195 acres in the central part of SRS. The BGC consists of several adjacent facilities that served as a former disposal site for radioactive and hazardous waste. SRS' Environmental Restoration Division had identified its highest priority site as the Burial Ground Complex. About 160 acres of the complex contains hazardous and radioactive waste disposal sites that require remediation. The $B G C$ is divided into a northern area containing approximately 119 acres and a southern area containing approximately 76 acres.

The northern area of the BGC is referred to as the Low Level Radioactive Waste Disposal Facility (LLRWDF). Disposal activities in this area began in 1970 and were discontinued in 1995. Waste in the LLRWDF has been disposed of in unlined trenches, engineered trenches and boreholes, surface storage pads and buildings, and underground tanks for storage of spent solvents. In March 1986, it was determined that some of the waste disposed of in the LLRWDF contained hazardous waste. This portion of the LLRWDF area was designated as the 58 acre Mixed Waste Management Facility (MWMF) and was closed under RCRA in 1990. Additional facilities within the remaining portion of the LLRWDF (trenches, boreholes, and solvent tanks) are in the process of closure under the Resource Conservation and Recovery Act (RCRA).

The southern area--the Old Radioactive Waste Burial Ground (ORWBG)--occupies 76 acres. Solid radioactive waste produced at SRS and waste shipped from other DOE and Department of Defense (DOD) facilities has been disposed at ORWBG. This area contains waste trenches covered with four feet or more of soil to reduce surface radiation levels. In addition, 22 tanks, once used to store spent radioactive process solvents, are buried in this section. (Place Fig. 1 here, Burial Ground Complex Map) 


\section{MIXED WASTE MANAGEMENT FACILITY CLOSURE}

The closure plan for the MWMF called for trench waste stabilization to prevent further subsidence and a clay cap to minimize contaminant migration. The MWMF closure was based on the results of several studies including induced settlement test, a clay cap test program, a study of the seismic effects of dynamic compaction on other disposal facilities in the LLRWDF and a clay cap subsidence repair zone evaluation. Dynamic compaction and surcharging were determined to be the most effective and practical methods for reducing settlement. To reduce the potential for rainwater infiltration and further migration of contaminants from the waste site a low permeability cover was placed on the MWMF. This cover included 3-foot-thick clay cap with a permeability of less than or equal to $1 \times 10-7 \mathrm{~cm} / \mathrm{sec}$. A 2-foot layer of topsoil was placed over the cap, and shallow-rooted grasses planted to hold the soil in place. The cap, soil covering and grass increase drainage and prevent rainwater infiltration of the underlying waste. Concrete drainage structures were constructed throughout the facility to carry rainwater away from the site. Current activities at the MWMF involve routine monitoring and maintenance as required by the RCRA permit. Closure of the MWMF began in January 1988 , and was completed in December of 1990 , at a cost of $\$ 35$ million.

\section{THE LOW LEVEL RADIOACTIVE WASTE DISPOSAL FACILITY (LLRWDF) CLOSURE}

Solid low level radioactive waste continued to be disposed of in the trenches outside the MWMF, but inside the boundaries of the active LLRWDF. In January 1990, it was determined that some of the waste disposed post March 1986 may have contained RCRA F-Listed, solvent laden rags. Consequently, per a settlement agreement with The South Carolina Department of Health and Environmental Control (SCDHEC), the MWMF was expanded to close these suspect solvent rag trenches. The suspect solvent rag area covers approximately 13 acres (e.g.18 earthen trenches, 3 Engineered Low Level Trenches (ELLT), four experimental greater-confinement disposal (concrete) engineered trenches, and 20 greater confinement boreholes). An additional 11 acres is being closed to accommodate the cover system configuration.

At the LLRWDF, SRS installed the first geosynthetic cap approved by the State of South Carolina for use at a hazardous waste site. Multi-layered, lightweight and impermeable, geosynthetic caps are a combination of sandy clay and high-density polyethylene products. The technology replaces the four feet of rock and clay used by the traditional kaolin clay cap with approximately two inches of geosynthetic material. This capping system is easier to install thus reducing construction time by approximately 20 percent. The system is also easier to maintain, because unlike traditional kaolin caps, geosynthetic caps are flexible and resist cracking. This resistance of cracking minimizes rainwater infiltration to waste sites. This alternative to traditional kaolin clay caps -- geosythetic cap closure technology -- expedites cleanup and reduces costs. The savings are estimated to be $\$ 100,000$ per acre over the life of the caps. . 
The geosynthetic cap has seven layers: a foundation layer, geosynthetic reinforcement layer, geosynthetic gas vent layer, geosynthetic clay liner, flexible membrane liner, geosynthetic drainage layer, and a vegetation layer. The foundation layer is soil, graded and compacted to provide a stable base for the geosynthetic materials. It provides adequate drainage for the cap, while the geosynthetic reinforcement layer supports the closure in the event of future waste decomposition and void development. The gas vent layer facilitates the safe collection and venting of methane gas as organic type waste decomposes.

Serving as the lower component of the impermeable hydraulic barrier, the geosynthetic clay liner uses bentonite clay placed between two geotextile materials. When wet, the clay swells, absorbing the water, effectively preventing water seepage to the waste below. Since the cap is laid down in sections that are needle punched together, bentonite clay is added at seam overlaps to improve the integrity and impermeability of the seams. The upper component of the hydraulic barrier is the virtually impervious flexible membrane liner. The combination of the geosynthetic clay liner and the flexible membrane liner provides a water penetration defense that is three to five orders of magnitude greater than kaolin clay caps.

Fusion seaming of the flexible membrane liner provides two seams that are stronger than the material itself. Extrusion seaming is used where the fusion seaming method can not be used, such as at patched or hard to reach areas. A non-destructive test, the air pressure test, is performed on every inch of the seams, and destructive tests are performed at a prescribed frequency.

The geosynthetic drainage layer is installed on top of the flexible membrane liner. It provides effective transport of water from beneath the vegetation layer. Establishing the vegetation layer, a two-foot-thick layer of soil, is the final installation step. This layer prevents erosion and minimizes water infiltration. The upper six inches of this layer is topsoil, seeded with grasses such as Bahia, Bermuda and Brown-Top Millet. The layer is then mulched. Once the grass takes root and covers the entire cap, the majority of the rain water either runs off the cap into ditches and settlement ponds or is taken up by the grass root system, seldom traveling below this top soil layer [1]. (Place Fig. 2 here, Closure Cap Comparisons)

The LLRWDF closure is in progress and scheduled to be completed by September of 1998. 


\section{OLD RADIOACTIVE WASTE BURIAL GROUND (ORWBG)}

The ORWBG began receiving waste in 1952 and was utilized until 1972; however, according to historical records small quantities of waste primarily in retrievable form were disposed of until 1974. The disposal methods at the ORWBG consisted of earthen trenches excavated to a width of $20 \mathrm{ft}, 20 \mathrm{ft}$ in depth and up to $700 \mathrm{ft}$ long. These trenches were filled with various levels/types of radioactive waste materials. These materials include transuranic (TRU) waste, low-level radioactive waste, and intermediatelevel radioactive waste generated at SRS; and waste generated elsewhere. Trenches were covered with 4 feet or more of soil to reduce surface radiation to less than 6 millirem per hour (mrem/hr). Also located within the ORWBG are twenty-two underground storage tanks. These tanks were used in the past to store organic solvents.

The ORWBG area was also used for storage of contaminated equipment. In addition, the ORWBG contained several facilities and operations in the area that were not directly related to the burial of solid waste. These included two areas for the incineration of organic solvents, a sandblasting facility for decontaminating equipment, and some repair facilities.

The ORWBG contains radioactive and hazardous waste and spent solvents generated from plant processes. Examples of the materials disposed of at the ORWBG include the following:

- Small equipment, analytical waste, decontamination residues, soil, construction debris, pipes, jumpers, and other process equipment from the radiochemical separations area, lead shielding, fuel components, and spent deionizer resins, spent lithium-aluminum targets, and irradiated process oil from pumps

- Shipments from off site including military hardware

Early disposal records of waste buried in the ORWBG were limited prior to 1962. Following 1962, records were kept of the contents, radiation level, and approximate storage location of each shipment of waste to the ORWBG. Later this information was retroactively recorded, from existing written burial records and recollection of operating personnel, into an electronic database for future reference. Many of the waste volumes and radionuclide quantities were estimated, including information on waste disposed before 1962[2].

\section{Old Radioactive Waste Burial Ground Closure}

An interim action at the ORWBG was initiated to minimize contaminant migration. The objective of the interim action is to reduce stormwater infiltration through the waste layer, which will minimize contaminant migration to the water table. The interim action places a low-permeability soil cover over the unit along with topsoil and vegetation. The soil 
cover will be sloped to promote surface runoff, minimize surface erosion and control the leaching of hazardous substances from the source material. The soil cover consist of a low hydraulic conductivity layer with a minimum compacted thickness of 2 feet and nominal saturated hydraulic conductivity of $1 \times 10-5 \mathrm{~cm} / \mathrm{sec}$ or less. The top vegetative layer has a minimum thickness of 6 inches and is seeded with locally adapted perennial grasses. (Place Fig. 3 here, SRS Old Radioactive Waste Burial Ground)

Concurrently with the interim action, the standard CERCLA process is being followed to determine the final remedy for the unit. In lieu of the normal field investigation process, SRS has completed an extensive source term research process that included an evaluation of aerial photographs, construction drawings, health physics burial maps, the computerized burial record analysis (COBRA), and interviews with SRS staff both past and present. As part of this analysis, a detailed study was conducted to determine the constituents of interest (COI). As a result of this study the COIs identified for the ORWBG were cadmium, lead, mercury, volatile organic compounds, tritium, cesium137, plutonium-238, plutonium-239, strontium-90, unranium-235, uranium-238, carbon14 , cobalt-60, technetium- 99 , iodine- 129 and neptunium- 237 .

With the concurrence of the State and Federal regulatory agencies, this information was complied into one document and submitted in lieu of the standard RCRA Facility Investigation/Remedial Investigation Workplan.

In addition, this report also identified potential "hotspots" that may require special feasibility assessment during the development of the final remedy for the ORWBG. The identification of potential "hotspots" was based on the following criteria:

High concentrations and/or high levels of radioactivity

Persistence of high radioactivity levels through time

Burial type

Waste form

Mobility

Both radioactive and nonradioactive constituents were considered. These areas will be evaluated during the evaluation of remedial alternatives for possible in-situ treatment or excavation and disposal. The development of the CMS/FS is in progress. The Record of Decision (ROD) for this unit is scheduled for submittal in June 2000.

\section{Solvents Tanks S1-S22}

Twenty-two buried solvents are also included in the ORWBG operable unit. These tanks were installed between 1955 and 1968 and are constructed of thin walled milled steel. Hundreds of thousand of gallons of spent PUREX solvent from Separations facilities and smaller amounts of tritiated pump oil were stored in the tanks prior to the 1980s. The solvents were aged for about six months, during which time most of the short-lived gamma-emitting fission products decayed and the heavy alpha emitters settled out of the solvent. Drawing off the organic phase and burning it in shallow open pans in trenches 
periodically reduced the volume of the tanks. Open burning was suspended in 1972. The content of the tanks, except for an "unpumpable heel" was transferred to new tanks in the northern part of the BGC in the late 1970s and early 1980s.

Characterization of the solvent tanks contents will be performed to verify the remaining contents, which is estimated at 8,000 gallons, meets the Waste Acceptance Criteria established by the potential receiving facilities. In an effort to support the characterization of the solvent tanks, camera surveys are being conducted to determine the contents and structural integrity of the tanks. A potential interim action for the solvent tanks will be considered. Potential early actions include waste removal and tank stabilization.

\section{BURIAL GROUND COMPLEX GROUNDWATER}

All groundwater associated with the burial ground complex is being addressed under the RCRA Permit for the MWMF. The permit identifies four contaminant plumes (southwest, southeast, northwest, and northeast) originating from the Burial Ground Complex. An extensive system of groundwater monitoring wells around the BGC is monitored by SRS. Currently, 144 wells monitor groundwater quality in the uppermost aquifer beneath the BGC. Samples from the wells are analyzed for selected heavy metals, indicator parameters, radionuclides, VOCs, and other constituents. Current data indicate that metals, radionuclides, tritium, and VOCs have been released to the groundwater. Characterization efforts at the BGC, to determine the vertical and horizontal extent of groundwater and vadose zone soil contamination, are conducted in accordance with the SCDHEC approved BGC Field Investigation Plan (FIP). The BGC FIP includes installation of monitoring wells to characterize groundwater, collection of soil and surface water samples, direct push technology for collection of ground water samples, and aquifer testing. Phase II of the BGC FIP was implemented with activities including: cone penetrometer soil and water sampling, coring and geophysical logging, installing groundwater monitoring wells, and Hydropunch ${ }^{\circledR}$ water sampling at approved locations around the perimeter of the BGC. Ecological activities included soil and water sampling, soil and water toxicity testing, and biological tissue sampling. (Place Fig. 4 Here - Plume Concentrations of Tritium in the SRS Burial Ground Complex Groundwater)

\section{Southwest Plume}

The southwest plume contains the highest constituent concentration levels and is fully characterized. The nature and extent of this plume is documented in the RCRA Part B permit application. An ACL/MZ was prepared and submitted as a part of the RCRA permit. The ACL/MZ proposes risk-based levels as Groundwater Protection Standards (GWPS) for constituents detected in the plume. Two contaminants, tritium and tetrachloroethylene, exceed the ACL/MZ proposed limits and will require remediation. Evaluation of corrective action alternatives continues while regulatory agencies review the permit application. 


\section{Northwest and Northeast plumes}

The detection of these plumes was identified in the RCRA permit application. Field investigation activities in the northwest and northeast plumes are complete except for aquifer testing. Future work includes preparation of an ACL/MZ demonstration for each plume.

\section{Southeast Plume}

Characterization of the SE plume is underway. Further actions will depend on the results of the characterization activity. After characterization is complete the delineation of the nature and extent of this plume will be submitted to the regulatory agencies as a revision to the permit application.

SRS continues to work technology selection for remediation of the southwest plume, on groundwater modeling to support the corrective action planning, and characterization of the southeast plume.

\section{CONCLUSION}

The Burial Ground Complex represents one of the highest long-term risks to human health and environment at the Savannah River Site. Implementation of restoration activities at this unit, which began in 1990 at the MWMF, represents a significant step in the overall reduction of risk at the SRS. By safely and cost effectively implementing restoration activities at the Burial Ground Complex SRS will complete closure of the major surface units by 2003 .

\section{REFERENCES}

1. Westinghouse Savannah River Company, "Mixed Waste Management Facility Closure Plan (LLRWDF)," WSRC-Q-CLP-E-00001, Rev. 3, Westinghouse Savannah River Company, Savannah River Site, Aiken, SC.

2. Westinghouse Savannah River Company, "Workplan/RCRA Facility Investigation Report for the Old Radioactive Waste Burial Ground 643-E, S01S22 (U), Rev. 0, WSRC-RP-97-00127, Westinghouse Savannah River Company, Savannah River Site, Aiken, SC. 


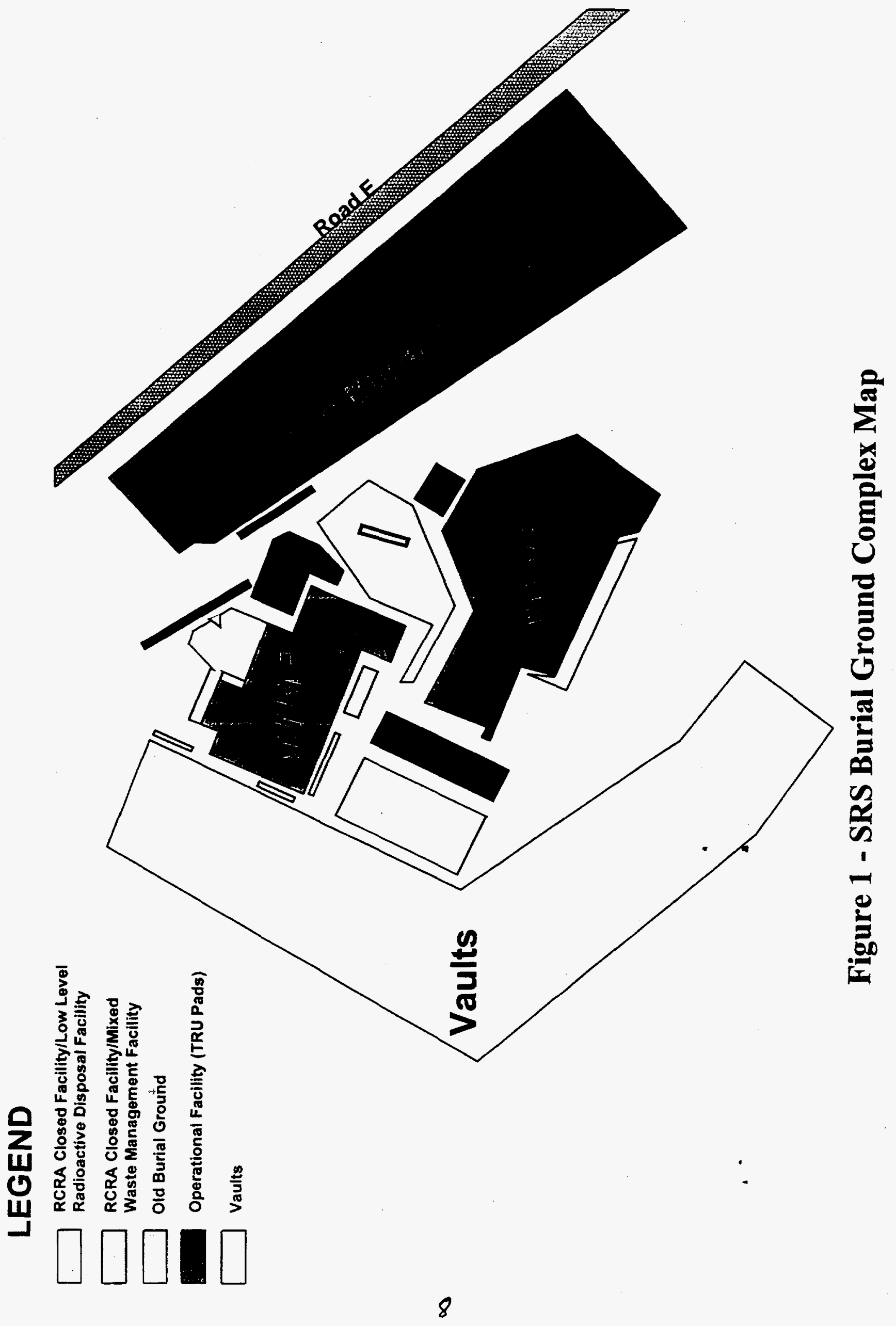




\section{Closure Cap Comparisons}
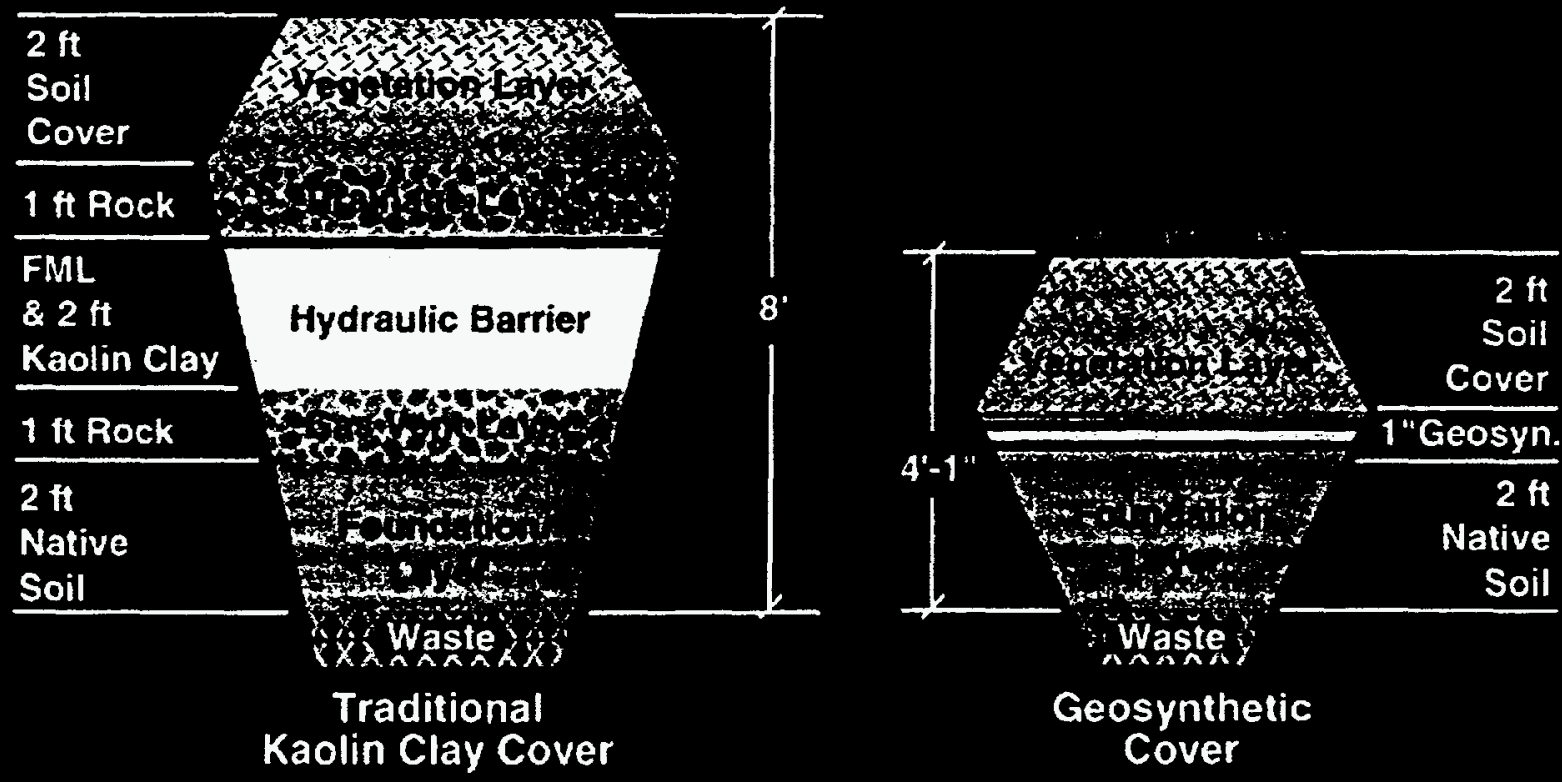

Geosynthetic

Cover

Figure 2 - Closure Cap Comparisons 


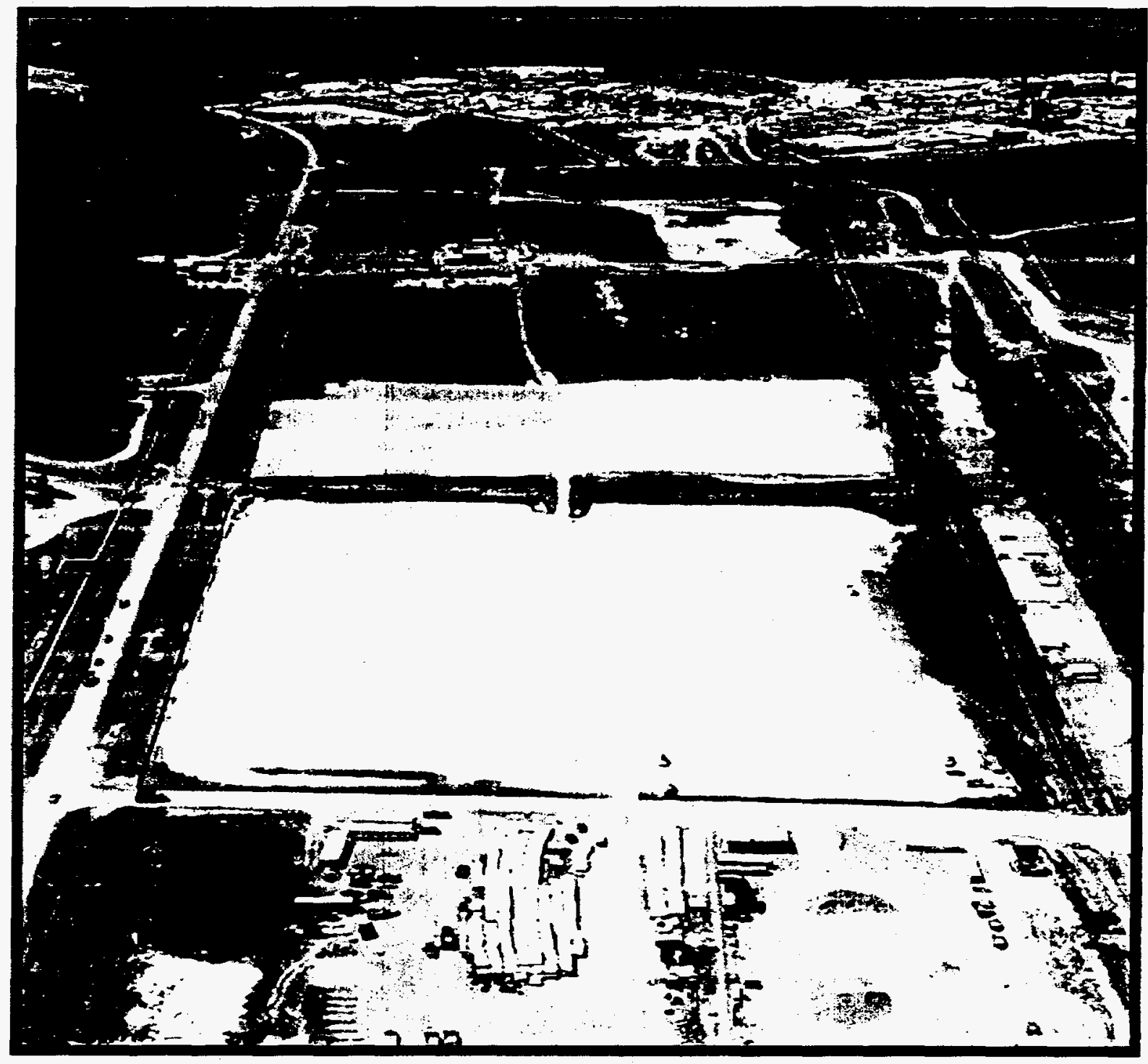

Figure 3 - SRS Old Radioactive Waste Burial Ground 

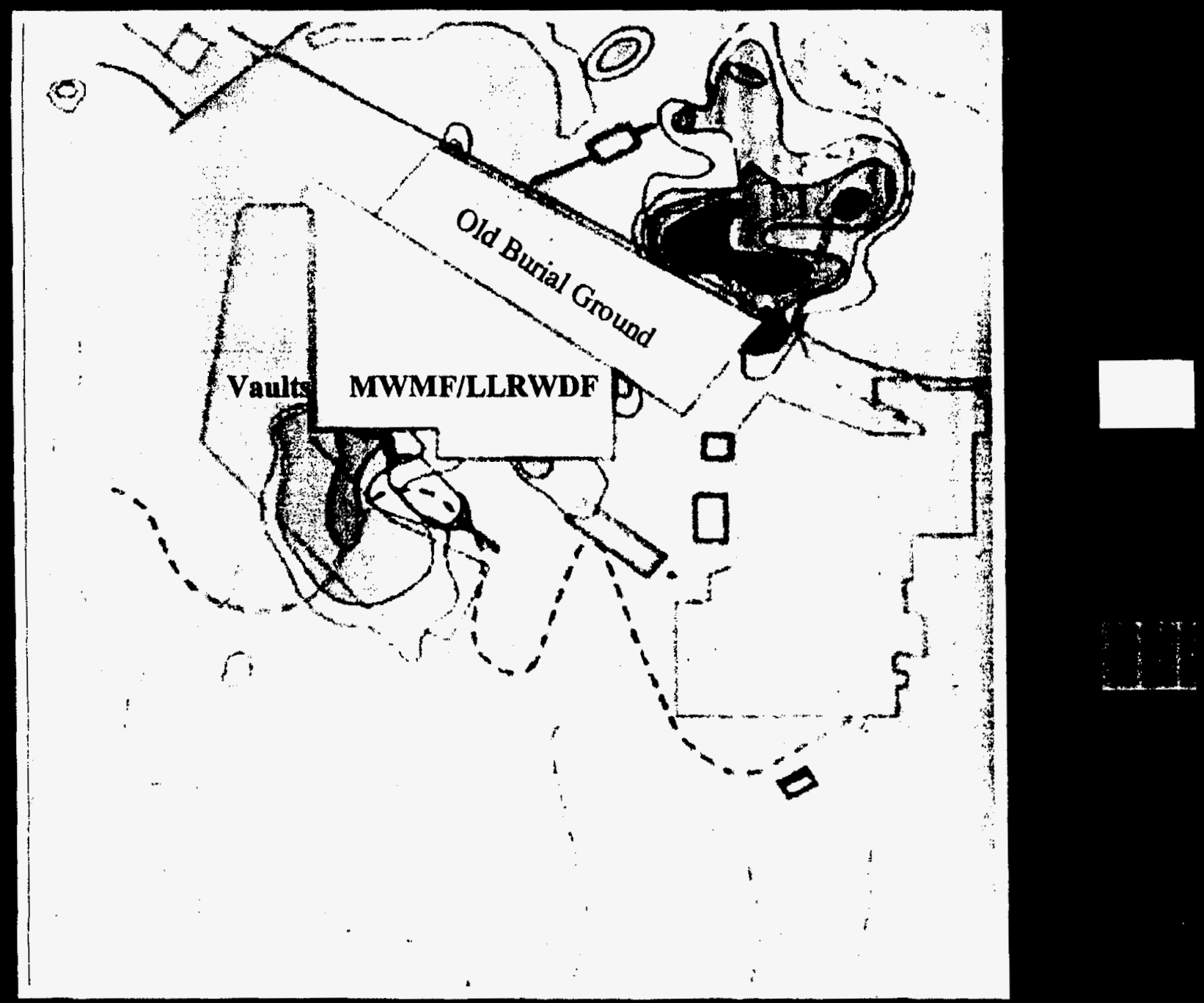

Figure 4 - Plume Concentrations of Tritium in the SRS Burial Ground Complex Groundwater 